\title{
Elevated pleural fluid RCAS1 is a diagnostic marker and outcome predictor in lung cancer patients
}

\author{
KEISUKE AOE ${ }^{1,2}$, AKIO HIRAKI ${ }^{1,2}$, KOICHI YAMAZAKI ${ }^{3}$, YUICHI NAKAMURA ${ }^{3}$, TOMOYUKI MURAKAMI ${ }^{2}$, \\ TADASHI MAEDA ${ }^{1,2}$, MASAHARU NISHIMURA $^{3}$, KAZURO SUGI $^{2}$ and HIROSHI UEOKA ${ }^{1}$

\begin{abstract}
Departments of ${ }^{1}$ Respiratory Medicine and ${ }^{2}$ Clinical Research, NHO Sanyo National Hospital, Respiratory Disease Center, Yamaguchi; ${ }^{3}$ First Department of Medicine, Hokkaido University Graduate School of Medicine, Hokkaido, Japan
\end{abstract}

Received February 2, 2006; Accepted March 30, 2006

\begin{abstract}
RCAS1, a type II membrane protein also secreted in soluble form, may be important in tumor cell evasion of immune surveillance and contribute to the aggressiveness of human tumors. We examined the implications of elevated pleural fluid RCAS1 at the onset of effusion in lung cancer patients. Of 102 patients presenting with pleural effusion, 59 proved to have a malignant effusion and 43, nonmalignant. Malignant effusions exhibited higher RCAS1 concentrations than nonmalignant effusions (mean $\pm \mathrm{SD} ; 36.3 \pm 114$ vs. 2.7 $\pm 1.8 \mathrm{U} / \mathrm{ml} ; \mathrm{p}=0.014$ ). Lung cancer patients with pleural fluid RCAS1 concentrations below $15 \mathrm{U} / \mathrm{ml}$ had a longer mean survival than those with higher concentrations (4.7 vs. 1.7 months; $\mathrm{p}<0.05)$. By multivariate analysis, pleural fluid RCAS1 was an independent prognostic factor in lung cancer patients with effusion. In conclusion, RCAS1 determination at onset of pleural effusion is informative for both diagnosis and outcome prediction in lung cancer patients.
\end{abstract}

\section{Introduction}

Lung cancer, the most frequent cause of cancer death, also is a major cause of pleural effusion. Approximately $10 \%$ of lung cancer patients have pleural effusion at the time of initial diagnosis, while 30-40\% develop pleural effusion later in the course of their disease (1). Differentiating malignant from nonmalignant pleural effusions is a critical clinical problem, and conventional methods have proven inadequate (2-5). Cytologic examination of pleural fluid fails to detect neoplastic cells in $40-50 \%$ of malignant effusions, and blindly obtained pleural needle biopsy specimens offer little additional sensitivity (6). Several investigators, therefore, have sought to improve diagnostic yield by measuring tumor markers in

Correspondence to: Dr Keisuke Aoe, Department of Respiratory Medicine and Clinical Research, NHO Sanyo National Hospital, Respiratory Disease Center, 685 Higashi-kiwa, Ube, Yamaguchi 755-0241, Japan

E-mail: keisukeaoe@mtf.biglobe.ne.jp

Key words: lung cancer, pleural fluid, diagnostic testing, RCAS1, survival outcome pleural fluid (7). A reliable clinical marker providing rapid and accurate diagnosis is greatly needed.

In addition to diagnostic issues, patients with malignant pleural effusion have a short life expectancy and are difficult to treat effectively (1). Pleural effusion in patients with lung cancer typically causes worsening symptoms including cough, pain, and dyspnea, which affect the quality of life, while increasing mortality. Development of a biologic marker that reliably reflects the state of pleural effusion would be useful in managing lung cancer patients with pleural effusion, facilitating timely and appropriate intervention.

A novel tumor-associated antigen termed receptor-binding cancer antigen expressed on SiSo cells (RCAS) 1, was first described in immunohistochemical studies of ovarian carcinoma (8). RCAS1 is a type II membrane protein thought to oligomerize through homotypic interactions between its Cterminal structures. RCAS1 acts as a ligand for a putative receptor present on normal cells including all peripheral lymphocytes (T, B, and NK cells). RCAS1 inhibits the growth of receptor-expressing cells and induces apoptotic cell death (9). In addition to its cell-membrane location, RCAS1 is secreted as a soluble protein (sRCAS1) detectable in fluids by enzyme-linked immunosorbent assay (ELISA) (10). We and other researchers have demonstrated that sRCAS1 might have value as a tumor marker (11-14). We suspected that this potential tumor marker had important clinical implications in lung cancer patients.

We presently studied 102 patients with pleural effusions of various etiologies to determine whether sRCAS 1 in pleural fluid could serve as a diagnostic indicator of lung cancer and a predictor of survival time. We found that sRCAS1 is elevated in malignant pleural effusion caused by lung cancer, as well as being potentially predictive of survival outcome.

\section{Materials and methods}

Patient and pleural fluid characteristics. We studied 102 patients with pleural effusion admitted to the Sanyo National Hospital between April 2000 and August 2003. Signs and symptoms, demographic data, and radiologic results were recorded. The characteristics of these patients are summarized in Table I. This patient group included 74 men and 28 women, with a mean age of 69 years; 59 patients $(58 \%)$ had malignant effusions, while $43(42 \%)$ had nonmalignant effusions. 
Table I. Patient characteristics.

\begin{tabular}{lr}
\hline No. of patients & 102 \\
Male/female & $74 / 28$ \\
Median age, years & 69 \\
Age range, years & $22-95$ \\
Diagnosis & \\
Malignant disease & 59 \\
Lung cancer & 45 \\
Malignant mesothelioma & 6 \\
Breast cancer & 4 \\
Other cancers (prostate, thyroid, stomach, uterus) & 4 \\
Nonmalignant disease & 43 \\
Tuberculosis & 21 \\
Infection other than tuberculosis & 10 \\
Heart failure & 4 \\
Rheumatoid arthritis & 3 \\
Other & 5 \\
\hline
\end{tabular}

Table II. Biochemical and serologic characteristics of malignant and nonmalignant pleural effusions.

\begin{tabular}{lccc}
\hline & $\begin{array}{c}\text { Malignant } \\
(\mathrm{n}=59)\end{array}$ & $\begin{array}{c}\text { Nonmalignant } \\
(\mathrm{n}=43)\end{array}$ & $\mathrm{p}$-value \\
\hline $\begin{array}{c}\text { Total protein } \\
(\mathrm{g} / \mathrm{dl})\end{array}$ & $4.60 \pm 0.88$ & $4.28 \pm 1.33$ & $\mathrm{p}=0.704$ \\
$\begin{array}{c}\text { Albumin } \\
(\mathrm{g} / \mathrm{dl})\end{array}$ & $2.59 \pm 0.61$ & $2.15 \pm 0.87$ & $\mathrm{p}=0.036$ \\
$\begin{array}{c}\text { Total bilirubin } \\
(\mathrm{mg} / \mathrm{dl})\end{array}$ & $0.87 \pm 1.17$ & $0.65 \pm 0.70$ & $\mathrm{p}=0.246$ \\
$\begin{array}{c}\text { LDH } \\
(\mathrm{IU} / \mathrm{L})\end{array}$ & $871 \pm 859$ & $978 \pm 837$ & $\mathrm{p}=0.358$ \\
$\begin{array}{c}\text { Cholesterol } \\
(\mathrm{mg} / \mathrm{dl})\end{array}$ & $92.9 \pm 34.0$ & $77.1 \pm 36.4$ & $\mathrm{p}=0.056$ \\
$\begin{array}{c}\text { Glucose } \\
(\mathrm{mg} / \mathrm{dl})\end{array}$ & $114.0 \pm 46.7$ & $116 \pm 62.6$ & $\mathrm{p}=0.743$ \\
$\begin{array}{c}\text { CEA } \\
(\mathrm{ng} / \mathrm{ml})\end{array}$ & $450 \pm 1296$ & $2.82 \pm 6.41$ & $\mathrm{p}<0.0001$ \\
\hline
\end{tabular}

Values shown are mean \pm standard deviation. LDH, lactate dehydrogenase; CEA, carcinoembryonic antigen.

Albumin and carcinoembryonic antigen (CEA) concentrations were significantly higher in malignant than in nonmalignant effusions. Total protein, total bilirubin, lactate dehydrogenase (LDH), cholesterol, and glucose concentrations in pleural fluid were similar between the two groups (Table II).
A

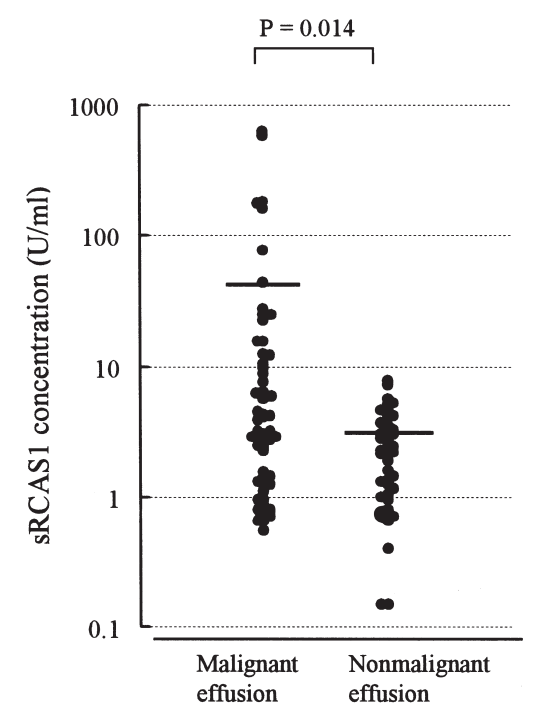

B

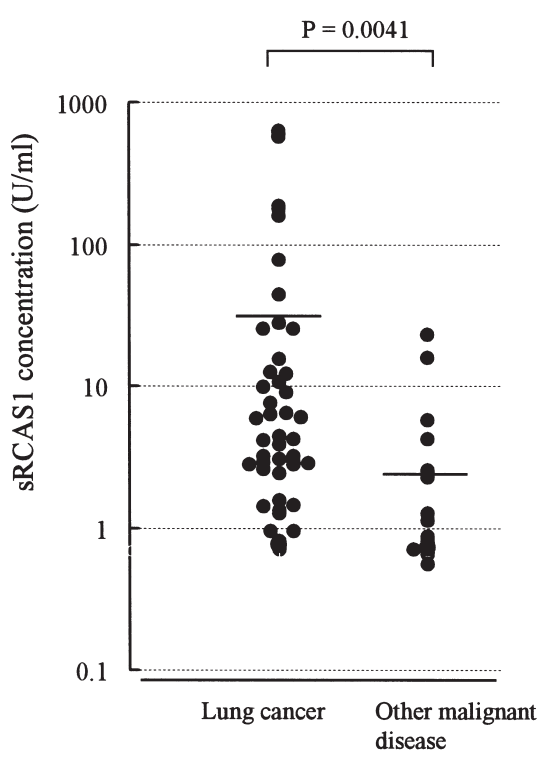

Figure 1. Concentrations of sRCAS1 in pleural effusions at onset. A, malignant effusions exhibited higher sRCAS1 concentrations than nonmalignant effusions (mean $\pm \mathrm{SD} ; 36.3 \pm 114$ vs. $2.7 \pm 1.8 \mathrm{U} / \mathrm{ml}$; $=0.014$ ). B, pleural fluid sRCAS1 concentrations in lung cancer patients were higher than those in patients with other malignant diseases (mean $\pm S D ; 46.3 \pm 129$ vs. $4.23 \pm 6.58 \mathrm{U} / \mathrm{ml} ; \mathrm{p}=0.041)$. Horizontal bars represent mean values.

Diagnosis of malignant pleural effusion. Malignant pleural effusion was diagnosed from either pleural fluid cytologic findings or malignant cells identified in a pleural biopsy specimen. Alternatively, when both of these microscopic assessments yield negative results, malignant effusion was diagnosed when a primary cancer was known to have disseminated and pleural fluid concentrations of established tumor markers were elevated.

Sample collection and determination of sRCAS1 concentration. Each sample of pleural fluid was collected in a syringe during thoracentesis after written informed consent. Samples were divided into two equal portions; one for cell collection and immunostaining (next paragraph) and another for sRCAS1 
A

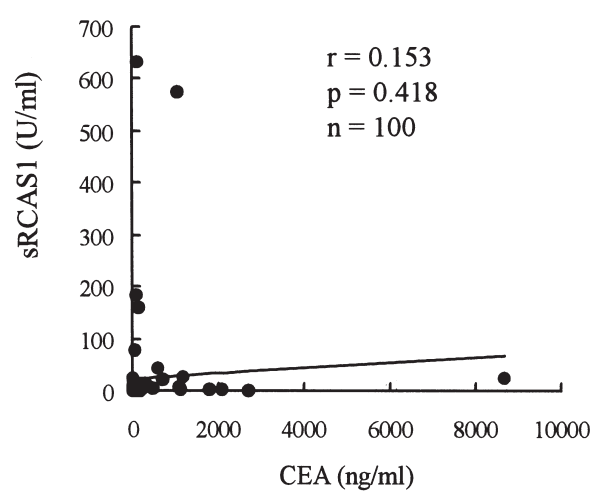

C

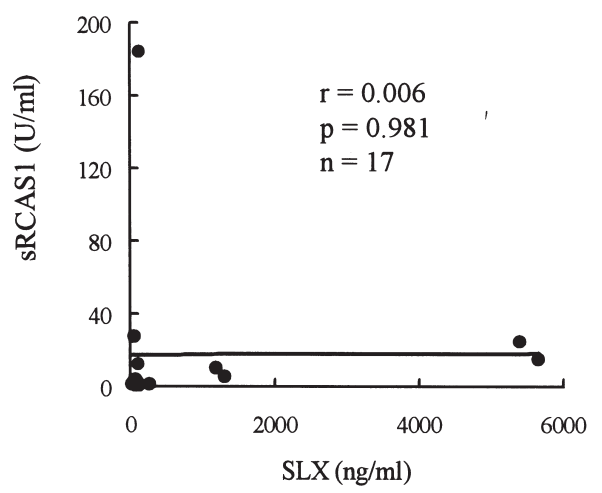

B

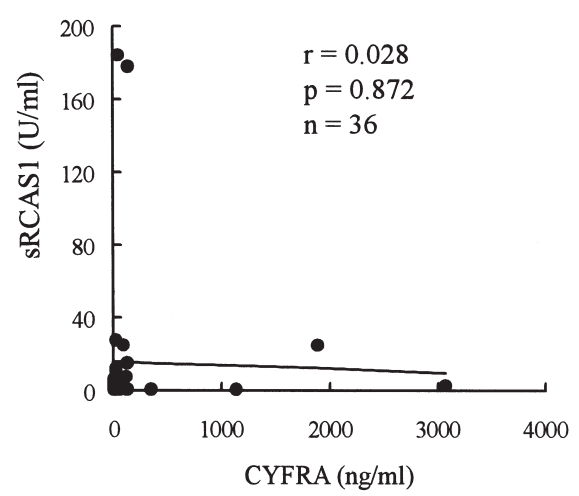

$\mathrm{D}$

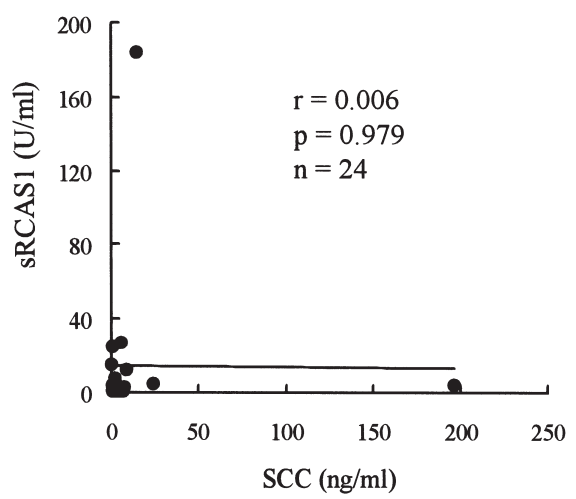

Figure 2. Correlation of pleural fluid sRCAS1 concentration with CEA (A), CYFRA (B), SLX (C), and ProGRP (D). No significant correlations were found between sRCAS1 and CEA ( $r=0.153, \mathrm{p}=0.418)$, CYFRA $(r=0.028, \mathrm{p}=0.872)$, SLX $(r=0.006, \mathrm{p}=0.981)$, or ProGRP $(\mathrm{r}=0.101, \mathrm{p}=0.829)$.

assay. The latter portion was centrifuged at $2000 \mathrm{rpm}$ for $10 \mathrm{~min}$, and the supernatant was frozen at $-80^{\circ} \mathrm{C}$ until assay for markers. Concentrations of sRCAS 1 were measured by sandwich enzyme-linked immunosorbent assay (ELISA) using commercially available kits (Medical \& Biological Laboratories, Nagoya, Japan).

Cell and tissue collection, and immunostaining. Lung cancer tissue specimens obtained from study patients who had undergone surgery at our hospital were fixed in formalin, dehydrated and then embedded in paraffin. Cells in pleural effusion were collected by centrifugation and then processed similarly. Sections of cells or tissues of $5 \mu \mathrm{m}$ in thickness were cut from paraffin blocks and affixed to glass slides. After deparaffinization and rehydration, the cells or tissues were stained with monoclonal anti-RCAS1 antibody (Medical \& Biological Laboratories, Tokyo, Japan), using a standard method reported previously (15). In brief, the cells were subjected to endogenous peroxide blockade with $3 \%$ hydrogen peroxide in methanol for $20 \mathrm{~min}$, and then treated with an agent (Histofine SAB-PO kit: Nichirei, Tokyo, Japan) to block nonspecific binding of antibody. Sections then were incubated with the primary antibody at a dilution of 1:500 overnight at $4^{\circ} \mathrm{C}$, followed by incubation with biotinylated secondary antibody and visualization using the Dako Envision system (Dako, Carpinteria, CA). Hematoxylin was used for counterstaining. A tissue section of a squamous cell lung carcinoma previously demonstrated to express RCAS1 was used as a positive control. Nonimmunized mouse IgM was substituted for the primary antibody in negative controls.

Statistical analysis. Differences between independent groups were examined by the Mann-Whitney $U$ test. Differences between more than two groups were determined by the Kruskal-Wallis test. Significance testing of correlations was evaluated using Spearman rank correlation analysis. A chisquared test or trend test was used to analyze the relationships between pleural fluid sRCAS1 concentration and categorical variables. Probabilities of survival were estimated using the Kaplan-Meier method, and survival differences between two patient groups were determined by the log-rank test. Prognostic factors were analyzed using the Cox proportional hazard model. Values of $\mathrm{p}<0.05$ were considered to indicate statistical significance.

\section{Results}

Diagnostic value of sRCAS1 in malignant pleural effusion. Malignant effusion exhibited higher RCAS1 concentrations than nonmalignant effusion (mean $\pm \mathrm{SD}, 36.3 \pm 114 \mathrm{vs}$. $2.7 \pm 1.8 \mathrm{U} / \mathrm{ml}, \mathrm{p}=0.014$; Fig. 1A). Pleural fluid sRCAS1 concentrations in patients with lung cancer were higher than 


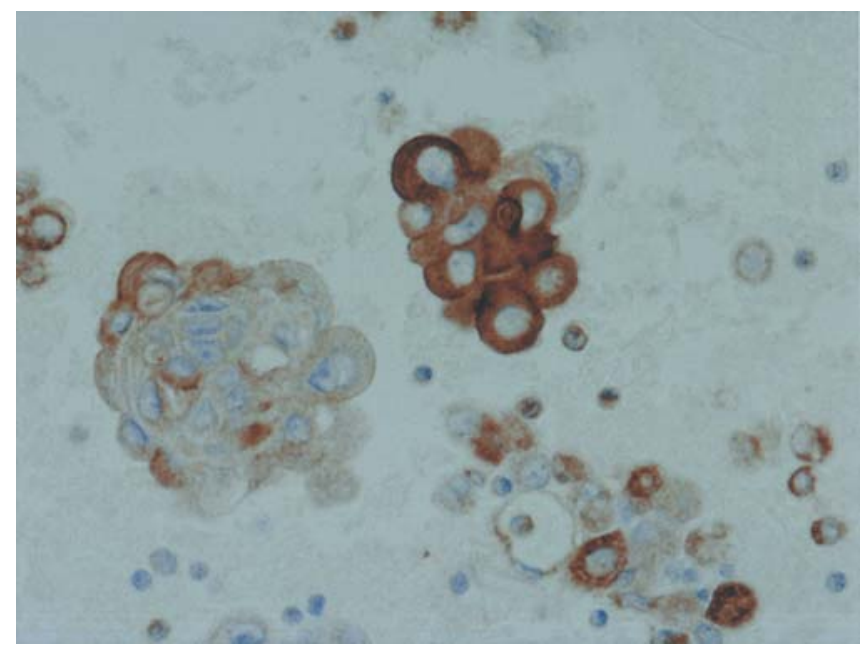

Figure 3. Representative photomicrograph of RCAS1 immunoreactivity in a cell block section prepared from pleural effusion in lung cancer patients (magnification, $\mathrm{x} 400$ ).

those in patients with other malignant diseases (mean $\pm \mathrm{SD}$, $46.3 \pm 129$ vs. $4.23 \pm 6.58 \mathrm{U} / \mathrm{ml}, \mathrm{p}=0.041$; Fig. $1 \mathrm{~B}$ ).
Expression of RCAS1 in the cell block section derived from malignant pleural effusion. To confirm that RCAS 1 is expressed by lung cancer cells in pleural effusion, we examined RCAS1 expression in immunohistochemically stained cell block sections prepared from malignant pleural effusion. In three of four such cases, lung cancer cell RCAS1 expression was confirmed in the effusion (Fig. 3). This finding strongly suggests that sRCAS1 in pleural fluid was secreted by lung cancer cells in the effusion.

Concentration of sRCAS1 in malignant pleural effusion associated with lung cancers. After we confirmed that the sRCAS1 concentration was elevated in malignant pleural fluid, we focused on the 45 lung cancer patients with malignant effusion. We first sought possible relationships between sRCAS1 and gender, age, histologic type of tumor, presence of distant metastases, Eastern Cooperative Oncology Group (ECOG) performance status (PS), serum LDH concentration, previous treatment, positive cytologic examination, serum total protein concentration, and location of pleural effusion. As shown in Table III, we found no significant correlation between sRCAS1 concentration and any of these clinicopathologic factors.

Table III. RCAS1 concentrations in pleural effusion of lung cancer patients.

\begin{tabular}{|c|c|c|c|c|}
\hline \multirow[t]{2}{*}{ Clinical variables } & & \multicolumn{3}{|c|}{ RCAS $1, \mathrm{U} / \mathrm{ml}$} \\
\hline & & $\mathrm{n}$ & Mean \pm SD & $\mathrm{p}$-value \\
\hline \multirow[t]{2}{*}{ Gender } & Male & 31 & $46.6 \pm 120$ & \\
\hline & Female & 14 & $45.5 \pm 152$ & 0.462 \\
\hline \multirow[t]{2}{*}{ Age, years } & $\leq 65$ & 16 & $25.5 \pm 56.2$ & \\
\hline & $>65$ & 29 & $57.8 \pm 156$ & 0.407 \\
\hline \multirow[t]{3}{*}{ Histologic type } & Adenocarcinoma & 38 & $53.7 \pm 140$ & \\
\hline & Small cell & 3 & $10.7 \pm 12.3$ & \\
\hline & Squamous & 4 & $2.78 \pm 6.58$ & 0.296 \\
\hline \multirow[t]{2}{*}{ Metastasis } & Yes & 30 & $56.7 \pm 155$ & \\
\hline & No & 15 & $25.5 \pm 46.9$ & 0.324 \\
\hline \multirow[t]{2}{*}{ ECOG PS } & 0,1 & 25 & $42.4 \pm 129$ & \\
\hline & $2,3,4$ & 20 & $51.2 \pm 134$ & 0.758 \\
\hline \multirow[t]{2}{*}{ Serum LDH } & $<450$ & 34 & $53.9 \pm 14.6$ & \\
\hline & IU/1 & $\geq 450$ & $1122.6 \pm 54.0$ & 0.653 \\
\hline \multirow[t]{2}{*}{ Previous treatment } & Yes & 22 & $43.2 \pm 137$ & \\
\hline & No & 23 & $49.3 \pm 124$ & 0.666 \\
\hline \multirow[t]{2}{*}{ Cytologic examination } & Positive & 28 & $56.9 \pm 159$ & \\
\hline & Negative & 17 & $2.7 \pm 55.5$ & 0.419 \\
\hline \multirow{2}{*}{$\begin{array}{l}\text { Serum total } \\
\text { protein, g/dl }\end{array}$} & $<6.5$ & 15 & $64.2 \pm 153$ & \\
\hline & $\geq 6.5$ & 30 & $37.4 \pm 118$ & 0.448 \\
\hline \multirow[t]{2}{*}{ Location } & Right & 31 & $60.3 \pm 152$ & \\
\hline & Left & 14 & $15.4 \pm 41.5$ & 0.286 \\
\hline
\end{tabular}

n, number of patients; LDH, lactate dehydrogenase; ECOG, Eastern Cooperative Oncology Group; PS, performance status. 


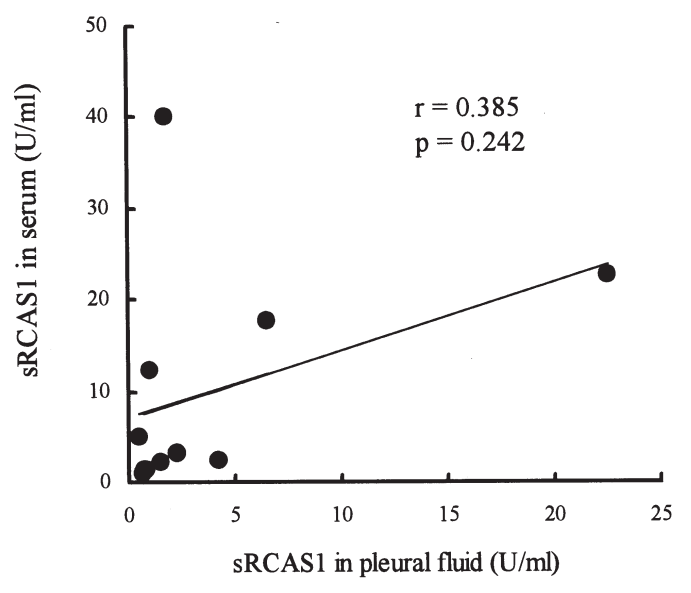

Figure 4. Lack of significant correlation between serum and pleural fluid concentrations of RCAS1 ( $\mathrm{r}=0.385, \mathrm{p}=0.242)$.

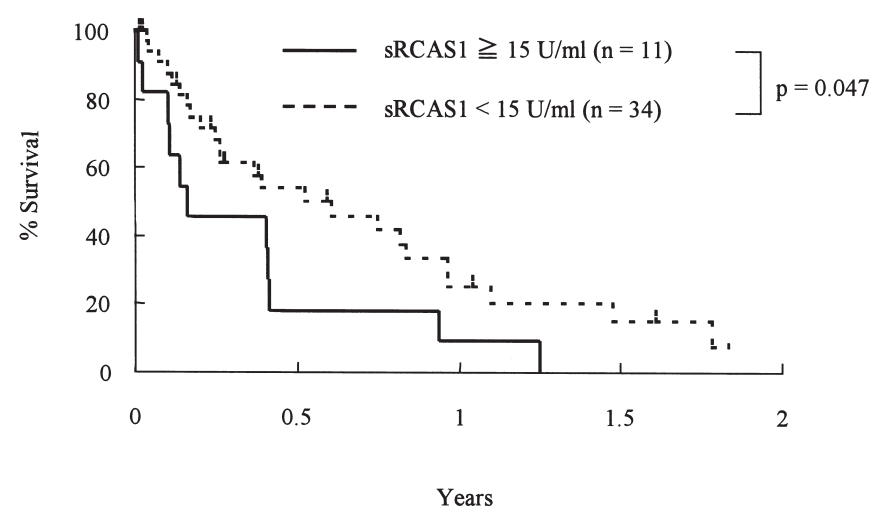

Figure 6. Relationship between pleural fluid RCAS1 concentrations at onset of pleural effusion and overall survival in lung cancer patients (KaplanMeier analysis). Survival of lung cancer patients with pleural fluid sRCAS1 concentrations of $<15 \mathrm{U} / \mathrm{ml}$ (dotted line) was significantly longer than survival of patients with concentrations of $>15 \mathrm{U} / \mathrm{ml}$ (solid line) ; (Median survival time, 4.7 vs. 1.7 months, $\mathrm{p}<0.05$ ). Numbers in parentheses indicate numbers of patients studied.

We next analyzed correlations between sRCAS1 and CEA, cytokeratin 19 fragment (CYFRA), sialyl SSEA-1 (SLX), or squamous cell carcinoma antigen (SCC) in malignant pleural fluid. As shown in Fig. 2, no significant correlations were found between sRCAS1 and CEA ( $\mathrm{r}=0.153, \mathrm{p}=0.418)$, CYFRA $(\mathrm{r}=0.028, \mathrm{p}=0.872), \operatorname{SLX}(\mathrm{r}=0.006, \mathrm{p}=0.981)$, or SCC $(\mathrm{r}=0.006$, $\mathrm{p}=0.979)$.

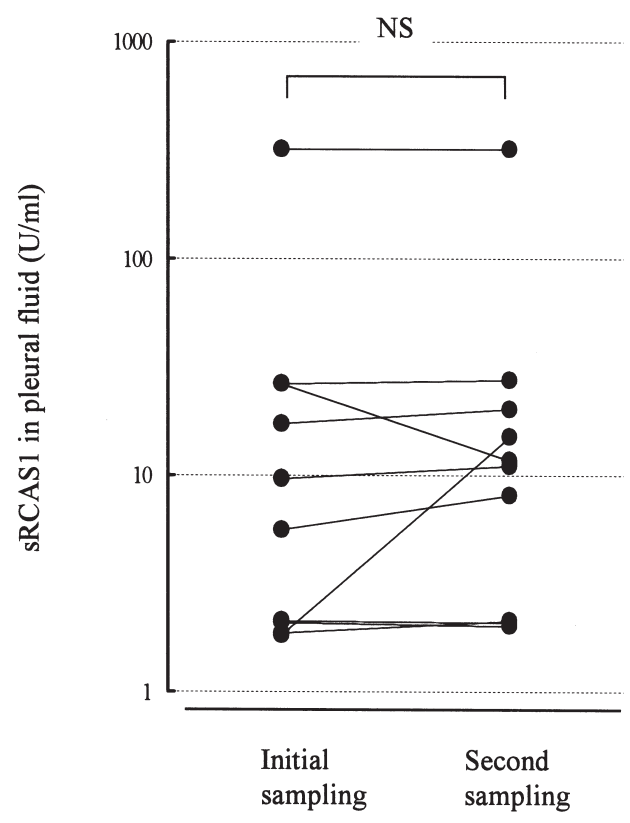

Figure 5. Lack of significant changes in pleural fluid RCAS1 concentrations during disease progression. The interval from first to second sampling ranged from 3 to 39 weeks.

In 10 lung cancer patients, serum was collected at the time of pleural fluid sampling to assess the possible correlation between serum and pleural fluid concentrations of sRCAS1 (Fig. 4); no correlation was evident. Malignant pleural effusion recurred in 10 lung cancer patients, after a median interval of 10 weeks (range, 3 to 39) following the first thoracentesis. The mean sRCAS1 concentration in the second pleural fluid sample was $16.9 \mathrm{U} / \mathrm{ml}$, showing no difference from initial samples (Fig. 5).

Only three specimens from the primary lung cancer site were available for immunohistochemical staining. In these cases, we found no relationship between degree of RCAS1 immunoreactivity at the primary site and pleural fluid sRCAS1 concentrations (Table IV).

Prognostic significance of pleural fluid sRCAS1 for lung cancer patients with malignant pleural effusion. The median survival time (MST) for all lung cancer patients in the current study was 4.8 months; the 1-year survival rate was $20.5 \%$. Prognostic significance of pleural fluid sRCAS1 concentration and other factors in patients with malignant pleural effusion

Table IV. RCAS1 expression in tumors and RCAS1 concentrations in pleural effusion.

\begin{tabular}{lcccccr}
\hline Patient no. & Age & Gender & Tumor & Histologic type & $\begin{array}{c}\text { Primary tumor } \\
\text { RCAS1 expression }\end{array}$ & $\begin{array}{c}\text { Pleural fluid } \\
\text { RCAS1 (U/ml) }\end{array}$ \\
\hline 1 & 42 & Female & LC & Adenocarcinoma & P1 & 4.2 \\
2 & 78 & Male & LC & Adenocarcinoma & P2 & 0.8 \\
3 & 74 & Male & LC & Adenocarcinoma & P2 & 12.4 \\
\hline
\end{tabular}

*According to the percentage of cells stained, our protocol divided specimens into four groups: no stained cells, P0; $1-5 \%$ of cells stained, $\mathrm{P} 1 ; 6-80 \%, \mathrm{P} 2 ; \geq 81 \%, \mathrm{P} 3$. LC, lung cancer. 
Table V. Prognostic factors in patients with malignant pleural effusion.

\begin{tabular}{|c|c|c|c|c|c|}
\hline Prognostic factor & & $\mathrm{n}$ & MST, months & 1-year survival, \% & p-value \\
\hline \multirow[t]{2}{*}{ Gender } & Male & 31 & 4.9 & 14.0 & \\
\hline & Female & 14 & 3.1 & 31.0 & 0.517 \\
\hline \multirow[t]{2}{*}{ Age, years } & $\leq 65$ & 16 & 9.8 & 37.7 & \\
\hline & $>65$ & 29 & 2.8 & 9.7 & 0.022 \\
\hline \multirow[t]{2}{*}{ sRCAS1, IU/ml } & $<15$ & 34 & 4.7 & 25.0 & \\
\hline & $\geq 15$ & 11 & 1.7 & 9.1 & 0.047 \\
\hline \multirow[t]{2}{*}{ Serum LDH, IU/1 } & $<450$ & 34 & 7.1 & 28.2 & \\
\hline & $\geq 450$ & 11 & 1.3 & 0.0 & $<0.001$ \\
\hline \multirow[t]{2}{*}{ ECOG PS } & 0,1 & 25 & 7.1 & 26.6 & \\
\hline & $2,3,4$ & 20 & 1.9 & 15.0 & 0.017 \\
\hline \multirow[t]{2}{*}{ Metastasis } & Yes & 30 & 6.2 & 23.3 & \\
\hline & No & 15 & 2.4 & 19.3 & 0.264 \\
\hline \multirow[t]{2}{*}{ Previous treatment } & Yes & 22 & 3.1 & 16.3 & \\
\hline & No & 23 & 4.6 & 24.9 & 0.549 \\
\hline \multirow[t]{2}{*}{ Location } & Right & 31 & 4.6 & 12.3 & \\
\hline & Left & 14 & 3.1 & 39.8 & 0.032 \\
\hline \multirow[t]{2}{*}{ Cytologic examination } & Positive & 28 & 3.1 & 20.2 & \\
\hline & Negative & 17 & 5.0 & 19.7 & 0.755 \\
\hline \multirow[t]{2}{*}{ Serum total protein, $\mathrm{g} / \mathrm{dl}$} & $<6.5$ & 15 & 2.0 & 12.4 & \\
\hline & $\geq 6.5$ & 30 & 4.9 & 23.6 & 0.638 \\
\hline
\end{tabular}

n, number of patients; MST, median survival time; LDH, lactate dehydrogenase; ECOG, Eastern Cooperative Oncology Group; PS, performance status.

was evaluated by univariate analysis (Table V). The cutoff value chosen for pleural fluid sRCAS1 concentration in lung cancer patients was $15 \mathrm{U} / \mathrm{ml}$, twice the maximum value in nonmalignant effusion specimens. High pleural fluid sRCAS1 concentration, high serum LDH, poor PS, older age, and right-sided pleural effusion were factors associated with poor survival. Survival in lung cancer patients with pleural fluid sRCAS 1 concentrations below $15 \mathrm{U} / \mathrm{ml}$ was significantly longer than in those with higher concentrations (MST, 4.7 vs. 1.7 months, p<0.05; Fig. 6).

To test the prognostic value of pleural fluid sRCAS 1 concentration, we performed multivariate analysis of prognostic factors using the Cox proportional hazards model. We found that pleural fluid sRCAS1 concentration $(\mathrm{p}=0.032)$ and serum LDH $(p=0.021)$ each had independent prognostic significance. ECOG PS ( $p=0.408)$, age $(p=0.151)$, and sidedness of pleural effusion $(p=0.714)$ lacked significant independent effects on survival (Table VI).

\section{Discussion}

In the current study, we found that profoundly elevated pleural fluid concentrations of sRCAS1 $(>15 \mathrm{U} / \mathrm{ml})$ measured at the onset of effusion correlated with shorter survival in lung cancer patients. Furthermore, multivariate analysis of prognostic factors identified pleural fluid sRCAS1 concentration as an independent prognostic factor for overall survival in lung cancer. These results suggest that sRCAS1 measured at the time of initial presentation with pleural effusion is an indicator not only for presence of lung cancer but also subsequent survival outcome.

Cytotoxic T lymphocytes recognizing tumor-specific antigens and NK cells are important in tumor elimination at early stages of cancer progression or metastasis (16). Because RCAS1-receptor expression is upregulated by activation of lymphocytes, RCAS1 helps to induce cell arrest and apoptosis in activated $\mathrm{T}$ and $\mathrm{NK}$ cells. These findings indicate that RCAS1 on tumor cells may convey an important advantage in avoiding host immune surveillance. RCAS1 is expressed in various cancers including those of the lung $(15,17)$, breast (18), esophagus (19), pancreas (20), liver (21), stomach $(22,23)$, gallbladder (24), and skin (25). RCAS1 expression also has been associated with aggressive tumor phenotypes, such as poor differentiation and advanced stage $(18,21,22)$. Furthermore, RCAS1 expression was reported to be significantly and negatively related to overall survival of patients with cancers of the lung $(15,17)$, esophagus (19), stomach (22), and gallbladder (24). Thus, RCAS1 facilitates the aggressive 
Table VI. Multivariate analysis of prognostic factors by the Cox proportional hazard model.

\begin{tabular}{lccc}
\hline & HR & $95 \%$ CI & p-value \\
\hline $\begin{array}{l}\text { Serum LDH } \\
\geq 450\end{array}$ & 1 & & \\
$<450$ & 0.246 & $0.075-0.810$ & 0.021 \\
$\begin{array}{l}\text { ECOG PS } \\
2,3, \text { or } 4\end{array}$ & 1 & & \\
0 or 1 & 0.645 & $0.228-1.823$ & 0.408 \\
$\begin{array}{l}\text { Age } \\
\geq 65\end{array}$ & 1 & & \\
$<65$ & 1.883 & $0.793-4.467$ & 0.151 \\
$\begin{array}{l}\text { Location } \\
\text { Right }\end{array}$ & 1 & & \\
Left & 0.844 & $0.341-2.091$ & 0.714 \\
sRCAS1, U/ml & & & \\
$\geq 15$ & 1 & & 0.032 \\
$<15$ & 0.404 & $0.177-0.924$ & \\
\hline
\end{tabular}

HR, hazard ratio; CI, confidence interval; $\mathrm{LDH}$, lactate dehydrogenase; ECOG, Eastern Cooperative Oncology Group; PS, performance status.

behavior of human tumors. In its secreted form, RCAS1 strongly suppresses immune cell proliferation and induces apoptosis in RCAS1 receptor-expressing cells, as does the transmembrane form (9). These results suggest importance for sRCAS1 in immune evasion by tumors. One inference from this is that sRCAS1 in effusion could be a good indicator for follow-up of lung cancer patients, as was supported by our results.

Differentiating malignant from nonmalignant pleural effusions is a critical clinical problem, and conventional methods have proven inadequate (26). Cytologic examination of pleural fluid fails to detect neoplastic cells in $40-50 \%$ of malignant effusions, and blindly obtained pleural needle biopsy specimens have shown little advantage in this respect (27). A reliable clinical marker for rapid and accurate diagnosis of malignant effusion is greatly needed. We previously reported preliminary studies suggesting that sRCAS1 could serve as a tumor marker for diagnosis of malignant pleural effusion (11). The current extended study including a larger number of patients confirmed our preliminary result, and suggested that RCAS1 determination in malignant pleural effusion at its onset should be diagnostically informative. In addition, we found no significant correlation between sRCAS1 and CEA, CYFRA, SLX, or SCC; potential markers in pleural fluid that have shown limited reliability when considered separately (7). Thus, our results suggest a role for sRCAS1 in a panel of diagnostic markers for malignant pleural effusion. Further studies of this specific possibility are needed.

In conclusion, sRCAS 1 concentrations in malignant pleural effusion associated with lung carcinoma are significantly higher than those in nonmalignant pleural fluid. Determination of sRCAS1 at the onset of pleural effusion is diagnostically informative, while sRCAS1 concentration is an independent prognostic factor that shows promise in follow-up of lung cancer patients who develop effusion.

\section{References}

1. Reed CE: Management of the malignant pleural effusion. In: Lung Cancer. Principles and Practice. Pass HI, Mitchell JB, Johnson DH and Turrisi AT (eds). Lippincott-Raven, Philadelphia, pp643-654, 1996.

2. Aoe K, Hiraki A, Murakami T, Eda R, Maeda T, Sugi K and Takeyama H: Diagnostic significance of interferon- $\gamma$ in tuberculous pleural effusions. Chest 123: 740-744, 2003.

3. Aoe K, Hiraki A, Murakami T, Murakami K, Makihata K, Takao K, Eda R, Maeda T, Sugi K, Darzynkiewicz Z and Takeyama H: Relative abundance and patterns of correlation among six cytokines in pleural fluid measured by cytometric bead array. Int J Mol Med 12: 193-198, 2003.

4. Hiraki A, Aoe K, Matsuo K, Murakami K, Murakami T, Onoda T, Sugi K, Takeyama $\mathrm{H}$ and Eda R: Simultaneous measurement of T-helper 1 cytokines in tuberculous pleural effusion. Int J Tuberc Lung Dis 7: 1172-1177, 2003.

5. Hiraki A, Aoe K, Eda R, Maeda T, Murakami T, Sugi K and Takeyama H: Comparison of six biologic markers for the diagnoses of tuberculous pleuritis. Chest 125: 987-989, 2004.

6. Fraser RS, Muller NL, Colman NC and Pare PD: Pleural disease. In: Fraser and Pare's Diagnosis of Disease of the Chest. Fraser RS, Muller NL, Colman NC and Pare PD (eds). Vol. 4, fourth edition. W.B. Saunders Company, Philadelphia, pp2739-2779, 1999.

7. Mohanty SK and Dey P: Serous effusions: diagnosis of malignancy beyond cytomorphology. An analytic review. Postgrad Med J 79: 569-574, 2003

8. Sonoda K, Nakashima M, Kaku T, Kamura T, Nakano H and Watanabe T: A novel tumor-associated antigen expressed in human uterine and ovarian carcinomas. Cancer 77: 1501-1509, 1996.

9. Nakashima T, Sonoda $\mathrm{K}$ and Watanabe T: Inhibition of cell growth and induction of apoptotic cell death by the human tumor-associated antigen RCAS1. Nat Med 5: 938-942, 1999.

10. Enjoji M, Nakashima M, Nishi H, Choi I, Oimomi H, Sugimoto R, Katoh K, Taguchi K, Nakamuta M, Nawata $\mathrm{H}$ and Watanabe T: The tumor-associated antigen, RCAS1, can be expressed in immune-mediated disease as well as in carcinomas of biliary tract. J Hepatol 36: 786-792, 2002.

11. Aoe K, Hiraki A, Maeda T, Murakami T, Yamazaki K, Sugi K and Takeyama H: Soluble receptor-binding cancer antigen expressed on SiSo cells (RCAS1) in pleural fluid: A potential diagnostic marker for malignant pleural effusion. Chest 126: 1195-1197, 2004

12. Leelawat $\mathrm{K}$, Watanabe $\mathrm{T}$, Nakajima M, Tujinda $\mathrm{S}$, Suthipintawong $\mathrm{C}$ and Leardkamolkarn V: Upregulation of tumor associated antigen RCAS1 is implicated in high stages of colorectal cancer. J Clin Pathol 56: 764-768, 2003.

13. Watanabe H, Enjoji M, Nakashima M, Noguchi K, Kinukawa N, Sugimoto R, Kotoh K, Nakamuta M, Nawata $\mathrm{H}$ and Watanabe T: Clinical significance of serum RCAS1 levels detected by monoclonal antibody 22-1-1 in patients with cholangiocellular carcinoma. J Hepatol 39: 559-563, 2003.

14. Enjoji M, Noguchi K, Watanabe H, Yoshida Y, Kotoh K, Nakashima M, Watanabe T, Nakamuta M and Nawata H: A novel tumor marker RCAS1 in a case of extramammary Paget's disease. Clin Exp Dermatol 28: 211-213, 2003

15. Oizumi S, Yamazaki K, Nakashima M, Watanabe T, Hommura F, Ogura S, Nishimura M and Dosaka-Akita H: RCAS1 expression: A potential prognostic marker for adenocarcinoma of the lung. Oncology 62: 333-339, 2002.

16. Whiteside TL and Herberman RB: The role of natural killer cells in immune surveillance of cancer. Curr Opin Immunol 7: 704-710, 1995.

17. Izumi M, Nakanishi Y, Yoshino I, Nakashima M, Watanabe T and Hara N: Expression of tumor-associated antigen RCAS1 correlates significantly with poor prognosis in nonsmall cell lung carcinoma. Cancer 92: 446-451, 2001

18. Rousseau J, Tetu B, Caron D, Malenfant P, Cattauzzi P, Audette M, Doillon C, Tremblay JP and Guerette B: RCAS1 is associated with ductal breast cancer progression. Biochem Biophys Res Commun 293: 1544-1549, 2002. 
19. Nakakubo Y, Hida Y, Miyamoto M, Hashida H, Oshikiri T, Kato K, Suzuoka M, Hiraoka K, Ito T, Morikawa T, Okushiba S, Kondo $\mathrm{S}$ and Katoh $\mathrm{H}$ : The prognostic significance of RCAS1 expression in squamous cell carcinoma of the oesophagus. Cancer Lett 177: 101-105, 2002.

20. Akashi T, Oimomi H, Nishiyama K, Nakashima M, Arita Y, Sumii T, Kimura T, Ito T, Nawata $\mathrm{H}$ and Watanabe T: Expression and diagnostic evaluation of the human tumorassociated antigen RCAS1 in pancreatic cancer. Pancreas 26: 49-55, 2003.

21. Noguchi K, Enjoji M, Nakamuta M, Nakashima M, Nishi H, Choi I, Taguchi K, Katoh K, Shimada M, Sugimachi K, Tsuneyoshi M, Nawata $\mathrm{H}$ and Watanabe T: Expression of a tumor-associated antigen RCAS1 in hepatocellular carcinoma. Cancer Lett 168: 197-202, 2001.

22. Kubokawa M, Nakashima M, Yao T, Ito K, Harada N, Nawata $H$ and Watanabe T: Aberrant intracellular localization of RCAS1 is associated with tumor progression of gastric cancer. Int $\mathbf{J}$ Oncol 19: 695-700, 2001.
23. Nakamura Y, Yamazaki K, Oizumi S, Nakashima M, Watanabe T, Dosaka-Akita $H$ and Nishimura M: Expression of RCAS1 in human gastric carcinoma: A potential mechanism of immune escape. Cancer Sci 95: 260-265, 2004.

24. Oshikiri T, Hida Y, Miyamoto M, Hashida H, Katoh K, Suzuoka M, Nakakubo Y, Hiraoka K, Shinohara T, Itoh T, Kondo S and Katoh H: RCAS1 as a tumor progression marker: an independent negative prognostic factor in gallbladder cancer. Br J Cancer 85: 1922-1927, 2001.

25. Takahashi $H$, Iizuka $H$, Nakashima $M$, Wada $T$, Asano $K$ and Ishida-Yamamoto A: RCAS1 antigen is highly expressed in extramammary Paget's disease and in advanced stage squamous cell carcinoma of the skin. J Dermatol Sci 26: 140-144, 2001.

26. Thunnissen FB, Peterse JL, van Pel R, Jansen JW, Ladde BE, Arends JW and Volvics A: Reliability of fine needle aspiration cytology for distinguishing between carcinoma, lymphoma, and sarcoma: the influence of clinical information. Cytopathology 4: 107-114, 1993.

27. Light RW: Pleural effusion. N Engl J Med 346: 1971-1977, 2002. 